\title{
THE MUD ADDITIVES AND THEIR EFFECT ON THERMAL CONDUCTIVITY OF ADOBE BRICKS
}

\author{
Mohammed Ali Bahobail \\ Department of Architecture and Building Sciences, College of \\ Architecture and Planning, King Saud University
}

(Received August 18, 2011 Accepted November 29, 2011)

\begin{abstract}
Adobe is one of the oldest building materials in use and abundantly found everywhere with affordable and reasonable cost. It is basically just dirt that has been moistened with water, sometimes with chopped straw or other fibers added for strength, and then allowed to dry in the desired shape. In addition to being simple and economic, adobe bricks are fireproof, durable, non-toxic, possess low sound transmission levels through walls and provide sufficient thermal mass to buildings.

Adobe brick walls are load bearing structures, which can be used to build up to several stories high. Also, adobe bricks have ability to build vaults and domes. In addition to this, adobe bricks afford great flexibility in the design and construction process. They can be simply cut, reshaped and can easily be subjected to opening to be use for building's services.

Besides having, these advantages; they have some disadvantages too which can be summarized as follows; moderately low compressive strength, low tensile strength, low scratch resistance and low water resistance. To overcome these defects, additives should be added to the soil to improve its quality and increase its capability to stand against these defects.

This paper provides an overview of the mud's additives that are used in different regions of the world, and their enhancement to improve the soil stability, including mineral, Synthetic, vegetable and animal additives. The paper also includes an experimental study that examines the thermal conductivity of mud brick mixed with some additives (plant oil, ash, soap, and cow dung).
\end{abstract}

\section{INTRODUCTION}

Adobe is another terminology used for "mud brick construction which is an Arabic and Berber word brought by Spaniards to the Americas, where it was adopted into English.

Adobe has been used for building for thousands of years. Basic Adobe bricks are made by mixing earth with water, and placing the mixture into moulds and left drying the bricks in the open air, away from direct sun. Mud mortar is used to join mud bricks together and can also be used as a plaster to cover the internal and external walls. [1][26].

Mud is considered inexpensive, broadly available and found environmentally friendly. It consists of stones, sand, silt, clay, and organic humus. Adobe construction is unsophisticated technique; easy-to-learn, and does not need specialized skills. This 
construction process relies greatly on human labor and creativity instead of on capital or high technology [4].

In contrast with adobe building, all construction materials used in a usual modern building are the product of energy-intensive processing. These industrialized processes also release toxic and hazardous chemicals into the water and the air. For example, around $4 \%$ of greenhouse gasses is emitted by manufacture of Portland cement. Moreover, modern construction depends on polluting trucks to transfer the fabricated materials from place to place, usually from hundreds of miles away [15].

Although, adobe bricks have some advantages; they have moderately low compressive strength, low tensile strength, low scratch resistance and low water resistance.

Therefore, additives can be used to improve its characteristic and to reduce these disadvantages. These additives are known as stabilizers, which can modify the properties of soil to manage its shrinkage, swelling and to improve its binding strength.

\section{THE OBJECTIVE OF THE STUDY}

This research aims to throw some lights on characteristics of additive materials. In addition, the paper investigates the thermal conductivity of mud brick mixed with some selected additives (plant oil, ash, soap, and cow dung).

The research will consider four different categories of additives listed below:

- Mineral additives: which include Sand, Pozzolana and Ashes.

- Synthetic additives: which include Portland cement, hydraulic lime, hydrated lime, gypsum, magnesium oxide, soap and bitumen.

- Vegetable additives: which include fibers, oils, fats, Tannins, gum Arabic, Palmo copal, Sap and latexes and molasses.

- Animal additives: which include fiber, Excrements, urine, blood, casein, animal glues and oil-fats.

\section{THE SIGNIFICANT OF THE STUDY}

The importance of the study stems from the fact that the entire world, at the present, heading towards the sustainable architecture. Adobe building is considered as one of sustainable architecture, due to the following reasons:

- Mud is available everywhere and can be consume without depletion of the resource base.

- Adobe brick can be recycled without harming the environment.

- Adobe buildings have important advantages in saving energy. In hot dry climates; adobe buildings have ability to keep cool air throughout day time and warm air during the night.

Thus, making the adobe constructions are worth for more investigation, including the preparation and additives techniques.

\section{MUD'S SPECIFICATION:}

Dirt used for adobe brick should have a high enough clay content to make the brick humidity resistant and more strength. However, brick with too much clay in it will develop shrinkages upon drying. To overcome this, sand must be added. 
The recommended mixture of adobe bricks are $15 \%$ of gravel, $50 \%$ sand, $15 \%$ clay and $20 \%$ mud. With this composition, adobe bricks provide good structural behavior, but they need protection from extreme weather conditions or continuous exposure to high moisture.

In the other hand, although, adobe walls compressive strength are relatively low, adobe brick can be used for load-bearing walls up to several stories high, Shbam's buildings in Yemen, for examples. The Shebam's buildings are 8 stories high that have stood for centuries. Other than walls, mud has flexibility to build vaults and domes.

In addition, Adobe brick possess very good sound insulation properties, and excellent thermal and fire resistance.

\section{ADDITIVES}

The additives are components that when mixed with mud, improve its physical properties and its performance. These physical properties are: compression strength, density, porosity, water absorption, depth of penetration, abrasion resistance and hardness.

The common additives can be divided in to three categories: minerals, synthetic and organic materials.

There are two sources of organic materials; a vegetable source, e.g., straw, palm leaves, and rice husks, and an animal source, e.g., animal hair and dung) (Torraca, 1988).

The additives should be water resistant, not closed pores and capillaries, and they should have good penetration. They ought to increase the mechanical strength and abrasion resistance. They must be durable, easily applicable, cheap, reversible and they should not be chemically hazardous [3].

Most of these additives are widely available, inexpensive or might be free.

The additives quantity varies from case to case based on the type of the additives and the soil conditions. The precise quantities of additives derived as a knowledge of experience, particularly from sensory observation, and field experiment, and by trial and error for each particular situation.

The laboratory tests can be used as guidance for field test. A simple test can be applied to test the characteristic of the soil. For example, mixing a bucket of dirt with a little water will indicate how well the soil adheres itself. If it can be molded and rolled into balls, with a little effort, this might indicate that the dirt is suitable for use. If it pulls does not form into balls easily, then the sand content is probably too high and the dirt might needs some additives. Another example, soaking the adobe brick in water, will indicate its water resistance and whether it needs additives or not.

\subsection{Mineral additives:}

\subsubsection{Sand}

Sand is a natural grainy material composed of finely rock and mineral particles. The composition of sand is extremely inconsistent, depending on its sources and conditions, but the most common sand consists of silica (silicon dioxide- $\mathrm{SiO} 2$ ), in the form of quartz. 
The size of the sand particles ranges in diameter from $0.0625 \mathrm{~mm}$ to $2 \mathrm{~mm}$. Each particle in this range size is called "sand grain"[29].

Sand is used when the soil has too much clay to obtain a more uniform grain size distribution. It improves cohesion between particles of the soil. In addition, it reduces the shrinkage and swelling characteristics by giving a better pore size distribution and higher density.

Sand should be uniformly mixed with the soil. Therefore, if the mixing is carried out in a dry, humid or plastic state, the soil first needs to be crushed to break up any lumps present in the mix. Another solution is to mix the soil in a liquid state.

\subsubsection{Pozzolana}

Pozzolana is another mineral additive, also known as pozzolanic ash, is a fine, sandy volcanic ash, originally discovered in Italy at Pozzuoli in the region around Vesuvius, but later at a number of other sites. Pozzolana consists of a siliceous and aluminous material which reacts with calcium hydroxide (hydrated lime) in the presence of water to form compounds possessing cementitious properties [19].

The Greeks and the Romans were the earliest societies known to use pozzolanas in lime mortars . Romans engineers used to grind pozzolana with powdered hydrated lime to use them instead of sand in concrete and mortared rubblework giving extraordinary strength

They mixed two parts by weight of pozzolana with one part of lime to mortar and concrete in masonry and brickwork, giving extraordinary strength [21].

\subsubsection{Ashes}

Ash is the finest of coal ash particles. Fly ash is the fine powder formed from the mineral matter in coal. It is components vary considerably depending upon its source, but most fly ashes contain significant amounts of silicon dioxide ( $\mathrm{SiO} 2)$ and calcium oxide $(\mathrm{CaO})$.

The woody plant ashes cannot be used as additive materials as the ash from the plants would contain too much of carbon. It can be excepted from that, the ashes which come from certain plant residues such as rice husks of which the silica contents are high.

Ash can be referred to as either cementitious or pozzolanic material. A cementitious material is one that hardens when mixed with water. A pozzolanic material will also harden with water but only after interaction with an alkaline substance such as lime. These cementitious and pozzolanic properties are what make some ashes useful as additive materials [25].

Ash is usually added in proportions of $10 \%$ by weight. Although it can improve compressive strength and reduce shrinkage and swelling. It has less effect on water resistance and low resistance to abrasion [8][9][12].

\subsection{Synthetic additives:}

\subsubsection{Portland cement}

Ordinary Portland cement (OPC), is the most common type of cement used in building construction. It is a fine powder which is produced by grinding and heating the 
Portland cement clinker in a kiln (more than 90\%), and by adding $5 \%$ calcium sulfate to controls the setting time.

Portland cement clinker is a hydraulic material, consists of two-thirds of calcium silicates $(3 \mathrm{CaO} . \mathrm{SiO} 2$ and $2 \mathrm{CaO} . \mathrm{SiO} 2)$ by mass, and the other one third consists of alumina, iron and other compounds.

Cement is used to improve the dry compressive strength and the wet compressive strength. Also cement gives the adobe brick resistance to erosion, rain and abrasion. To have a good quality, it is important that the cement is well-mixed with the soil. Based on the type of the soil, some soils require only a $3 \%$ addition of cement, but normally it ranges from 2 to $15 \%$, the higher the shrinkage of the soil the higher the proportion of cement used [23].

\subsubsection{Hydraulic lime}

Hydraulic lime is a calcium carbonate, which can be used to produce mortar and plaster products. To make hydraulic lime, limestone is mixed with clay under high temperatures. This process eliminates the moisture from the lime and produces mineral known as silicates. The remaining limestone and silicates are combined to form hydraulic lime.

Hydraulic lime has a number of advantages. The most important of them is its ability to cure and harden when wet.

It is less dense and very porous, which allows buildings to "breathe", and does not keep moisture in the brick. Also, Hydraulic lime has a low modulus of elasticity, resulting in fewer cracks due to expansion and contraction. In addition, hydraulic lime is used for providing a faster initial set than hydrated lime.

\subsubsection{Hydrated lime}

The term Hydrated is used due to reason that the calcium oxide $(\mathrm{CaO})$ has been hydrated with just enough water to turn the $\mathrm{CaO}$ into calcium hydroxide $\mathrm{Ca}(\mathrm{OH}) 2$. The Hydrated lime makes the clay more cohesive and hard. In addition, Hydrated lime has ability to absorb carbon dioxide from the air gradually to transform into calcium carbonate $(\mathrm{CaCO} 3)$, or limestone.

Hydrated Lime should be added to the soil at least 2, but preferably 8 to 16, hours before the stabilization takes place, to make the soil easier to work and compact. Lime is suitable to soils that have high proportion of clay, and the recommended proportion is 3 to $10 \%$ but usually at the upper end of this range [20]. Unlike hydraulic lime, hydrated lime has a medium setting time, but it sets harder by absorbing carbon dioxide from the atmosphere [18][24].

\subsubsection{Gypsum}

Gypsum is one of the more common by used mineral which can be found in sedimentary environments. Pure gypsum is a white to transparent mineral, its chemical term is calcium sulfate dehydrate, $\mathrm{CaSO} 4 \cdot 2 \mathrm{H} 2 \mathrm{O}$ [7].

When gypsum is heated, it loses about $0.75 \%$ of its water and becomes hemihydrates gypsum $(\mathrm{CaSO} 4 \cdot 1 / 2 \mathrm{H} 2 \mathrm{O})$. The hemihydrates gypsum is a soft mineral, and can be easily grinded to a powder which can be used in building construction. 
Gypsum is not a common additive to soils. It sets quickly, and it is not moisture resistant, therefore, it should not be exposed to wet conditions. Usually it is used with a sandy soil in proportions of between 10 and 20\% [20].

Magnesium oxide

Magnesium oxide, or magnesia, is a white solid mineral. It is formed by an ionic bond between one magnesium and one oxygen atom. It is formed commercially by heating magnesite to $700-1000{ }^{\circ} \mathrm{C}$. At this temperature, magnesium carbonate thermally decomposes to produce magnesium oxide and carbon dioxide.

Magnesium oxide is used to increase the compressive strength of mud bricks. However, magnesium oxide has ability to absorb water molecules from the surrounding environment. Therefore, Care must be taken to protect magnesium oxside from humidity and moisture [11].

\subsubsection{Soap}

Soap is a cleansing agent made from the interaction of fats and oils with alkali. Oils of the soap are consisting of two main substances; glycerin and a fatty acid. The glycerin and the sodium salt of the fatty acid are produced by mixing oils with an alkali. The percentage of mixture of fats and alkalis affect on the hardness, lathering qualities, and transparency of soap. The suitable oils for making soap can be supplied by tallow, grease, fish oils, and vegetable oils.

To make soil waterproof, soap is mixed with the soil or applied as a surface finish. It reduces its sensitivity to water by about $25 \%$. Generally, very small quantities $(0.1$ or $0.2 \%)$ soap is added; however, because it is washed out by water, it needs periodic re-application if it is applied as a surface finish [20].

\subsubsection{Bitumen}

Bitumen is a mixture of organic liquids that is highly thick, black, sticky and completely soluble in carbon disulfide.

Usually, bitumen contains sulfur and other metals such as nickel, mercury, lead, chromium, vanadium, arsenic and selenium. It can be obtained by fractional distillation of raw oil, where it is the remaining fraction with the highest boiling point, as $525^{\circ} \mathrm{C}\left(977^{\circ} \mathrm{F}\right)$. Also, it can be obtained by fractional distillation of used motor oils.

In the other hand, bitumen can now be made from non-petroleum based such as sugar, molasses, rice, corn and potato starches [22].

It is difficult to mix raw bitumen with the soil, because it is too thick. There are two methods to make it more fluid for stabilization purposes; by mixing it with solvent materials, such as diesel fuel or kerosene or by using emulsifier.

Emulsions are produced by dissolving bitumen in water with the help of an emulsifier. This method is more common and suitable for many soil types. Emulsion is very fluid and easily mixed with moistened soils. When the mixture dried, the bitumen forms a thin film coating the soil particles.

The main important factor of adding bitumen is to improve soil cohesion and its water resistance. However, it should be noted that exceeding the recommended quantity might affect the soil compressive strength.

Normally the quantity of bitumen to be added is:

4 to $6 \%$ for a soil with a high sand content 
7 to $12 \%$ for soils with low sand content

13 to $20 \%$ for clayey soils.

It is recommended that a small quantity of soil is mixed with the bitumen before mixing it with the remainder. To keep stabilizer more effective, the mixing should be moderate to avoid breaking down the emulsion [10][23].

\subsection{Vegetable additives}

\subsubsection{Fibers:}

The fiber is created mainly from the plant cell walls which are mostly composed of carbohydrates and some other substances. The fibers are used to enhance the tensile strength, reduce cracking, decrease density and speed up drying. The soil improvement varies according to the fibers shape, size, strength, amount, elasticity and their bond strength with soil particles. Recommended proportion ranges between 1 and $4 \%$ by weight. The most commonly used fibers are from wheat, rice or barley. Also, the chaffs or husks of these crops are acceptable. In addition, there are other vegetable fibers can be used such as hay, hemp, millet, sisal, filao needles, and elephant grass.

One negative aspect of using vegetable fiber is that it decreases the compressive strength. Also, vegetable fiber has inconsistent durability. Generally, dry fibers will last a very long time but when wet they are liable to rot. Furthermore, some vegetable fibers are attacked by insects, especially termites [1][5][13].

\subsubsection{Vegetable Oils and Fats}

Vegetable oil is a chemical compound formed from one molecule of trihydric alcohol and three fatty acids. It is commonly used to improve the soil's moisture resistance. The effective additives types are those which indicate a noticeable hardening in contact with air, and are insoluble in water. Such additives are coconut, cotton and linseed oil as well as castor. Also, it is found that the Kapok, palmitic oil and shea butter can be used in some cases. It is worth mentioning that shea butter can repel termites. The recommended quantity is around $3 \%$, but also it can be painted or sprayed on surfaces [6].

\subsubsection{Tannins}

Tannins are polyphenol substances present in the seeds and stems of grapes, the bark of some trees, and tea leaves. It can be obtained by boiling the proper part of the plants.

Tannins are used to break up clay particles into small particles. So that the clay can coat the sand grains in the soil more consistently. Also, the tannins can help to reduce porosity of the soil and to improve its water resistance [23].

\subsubsection{Gum Arabic:}

Gum Arabic is a natural gum made of hardened sap which is obtained from the acacia tree. Also known as gum acacia, chaar gund, char goond or meska. It is a mixture of two organic substances; saccharides (carbohydrate) and glycoproteins gives it the properties of adhesion, and bonding. 
This increases the dry compressive strength, slows down the water absorption, and reduces the shrinkage. However, it must take into account that the gum Arabic is soluble in water and has little protection to long-term moisture exposure. The recommended quantity is 5 to $10 \%$ [13].

\subsubsection{Copal}

Copal is a resin obtained from a certain type of tropical trees such as manila copal. It looks hard, but will soften and melt when exposed to a hot flame. It is used to improve waterproofing property of the soil. It is usually added at 3 to $8 \%$ to sandy soils [28].

\subsubsection{Sap and latexes}

Latex is a milky sap-like fluid found in $10 \%$ of all flowering plants (angiosperms) such as euphorbia, hevea rubber and concentrated sisal juice [2]. It is a complex emulsion consisting of proteins, alkaloids, starches, sugars, oils, tannins, resins, and gums that becomes thicker when it is exposed to air. It is usually obtained by injuring the external tissue of the plants. It comes in different color, white (in most plants), yellow, orange, or cherry latex.

It is mixed with neutral soil to reduce its permeability slightly and improves its density. The recommended proportions are between 3 and 15\% [13].

\subsubsection{Molasses}

Molasses can be obtained from certain plants, sugar cane plant, for example. It is usually extracted by crushing or mashing the effective part of the plants and boiling it. Molasses contain aldehydes which can be transformed into polymers at high temperatures.

It is added to soil to improve its strength and reduce its permeability.

General content of molasses is about 5\% [13].

\subsection{Animal additives}

\subsubsection{Fibers}

Animal fibers (hair, fur and wool) are natural fibers that consist mostly of particular proteins. They play the similar role as vegetable fibers. It is used to improve adhesion and impact resistance of the plaster; hair and fur from animals are mixed with plasters and renders to reduce shrinkage [14].

\subsubsection{Blood}

Blood is made up of a liquid portion. Approximately 55 percent of blood is plasma, which carries the solid cells (red blood cells and white blood cells) and platelets which help blood clot in case of bleeding. Blood also carries hormones released by the endocrine glands and carries nutrients from food that has been processed by the digestive system.

The use of bull's blood has been known since Roman times. Blood can be an effective additive when mixed with lime, polyphenols or tannins. It is used to increase hardness and water resistance. The blood must be fresh and not in powder form [28]. 


\subsubsection{Casein}

Proteinic casein, in the form of whey, is a product formed by the souring of milk. It is used as soil stabilization. Sometimes, it is mixed with other substances such as animal blood [6]. Also, Casein can be used in painting by mixing it with white lime.

\subsubsection{Animal glues}

Animal glue is an adhesive that is created by boiling of animal connective tissue for long time to produce protein colloid glues. These protein colloid glues are formed through hydrolysis of the fibrous proteins found in skin, bone, and other connective tissues.

The purpose of adding animal glues to soil is to improve its strength and its property of water resistance.

\subsubsection{Oils and fats}

Animal oils and fats are extracted from the tissues by steaming or boiling them with water. In some cases, the extraction is done under increased pressure.

Different type of oils and fats of animal, include butter, tallow (the solid fat of cattle, sheep, or horses), fish oils, and whale oil, can be used as waterproofing agents. Content is variable based on the soil's condition.

\subsubsection{Urine}

Urine is usually consists of $95 \%$ water, urea, creatinine, uric acid, salt and ammonia and other elements and hormones. Urea is the principal component of urine, it is an organic compound with the chemical term ( $\mathrm{NH} 2) 2 \mathrm{CO}$. It is found that the urea act as binding material and it can be used to reduce soil shrinkage, eliminates cracking and improve the ability of the soil to withstand erosion. The suggested amount varies based on the percentage of sand in the soil. However, it can replace the mixing water in a sandy soil. In addition to this, good results were obtained when it was combined with lime [28].

\subsubsection{Excrements}

Waste material, especially fecal matter, that is expelled from the animal body after digestion. These can contain chemicals such as phosphoric acid, potassium minerals and fibers.

Cow, horse or camel dung is normally used. It improves the cohesion and plasticity of soils. Sometimes partially dry dung is applied to mud plaster to help stop the development of cracks. In India, a traditional waterproofing is made by mixing water with one part cow dung and five parts earth by weight, and applied to fill up surface cracks [27].

Goat dung can be used to lighten the soil. It is recommended to leave the mix of a soil and dung to ferment for several days before use. The suggested amount is up to one third, or up to one half for a finishing mix [13].

These, mineral, synthetic, vegetable and animal stabilizers, are the most mud additives which are commonly used in some parts of the world. The main advantage of these additives or stabilizers is their local availability as a cheap material. In addition, 
they can be found in abundance, and they can be produced by very simple processes which do not need high skills.

\section{THERMAL CONDUCTIVITY}

Thermal conductivity is defined as the time rate of steady heat flow, watts, through a unit area, $\mathrm{m} 2$, per unit temperature gradient in the direction perpendicular to an isothermal surface, "expressed as W/m.k (watts per meter kelvin).

Most of the studies which presented in the previous sections did not address the thermal conductivity; therefore, the next sections are devoted to study this property by using experimental test. The most four available additives are selected (one additive from each category: cow dung, soap, palm oil and ash) to be tested and investigate their effect on the thermal conductivity of the mud.

\subsection{Experimental Procedure:}

A 5\%,10\% and $15 \%$ (by mass) of four different additives (cow dung, soap, palm oil and ash) were mixed individually with adobe mud (40\% clay and $60 \%$ sand). Each sample was formed by using a wood mold. The mold was constructed of $1.0 \mathrm{~cm}$ thick, with internal dimensions of $10 \mathrm{~cm}(\mathrm{~L}) \times 5 \mathrm{~cm}(\mathrm{~W}) \times 5 \mathrm{~cm}(\mathrm{H})$. A mixed mud was poured into the mold, hand tamped, and leveled. The samples, then, were pulled out from the mold and left several days until became dry.

Quick Thermal Conductivity Meter "Kemtherm QTM-D3" (figure 1) manufactured by Kyoto Electronics- Japan, was used to examine the effects of mixing the mud with the additives on its thermal conductivity.

The Measurements take place by placing the thermal conductivity meter probe, which use the transient hot-wire method technique, on any flat sample face for only 60 seconds.

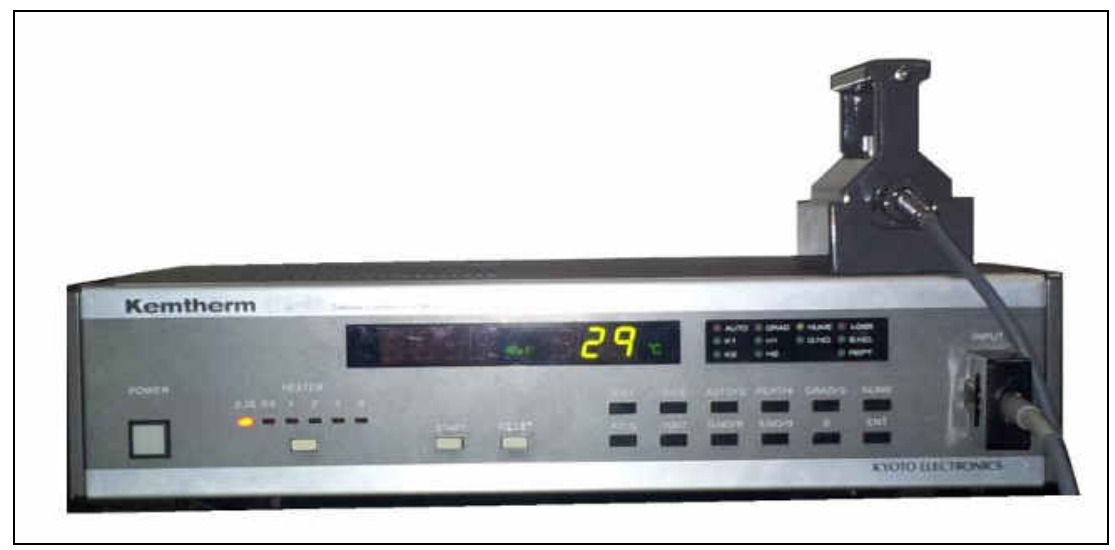

Figure (1): Quick Thermal Conductivity Meter "Kemtherm QTM-D3"

\subsection{Results:}

Experiments indicated that the mud brick samples with cow dung additive, soap additive and palm oil additive have a higher thermal conductivity, while the mud brick samples with ash additives have a low thermal conductivity comparing to the pure mud brick (table1-figure 2). 


\section{Table (1): Thermal conductivity of the samples}

\begin{tabular}{|c|c|c|c|}
\hline \multirow{2}{*}{$\begin{array}{c}\text { Mud brick's } \\
\text { sample }\end{array}$} & \multicolumn{3}{|c|}{ Thermal Conductivity (W/m.k) } \\
\cline { 2 - 4 } & $\mathbf{5 \%}$ & $\mathbf{1 0 \%}$ & $\mathbf{1 5 \%}$ \\
\hline With cow dung & 0.9006 & 0.9327 & 0.9405 \\
\hline With soap & 0.9149 & 1.060 & 1.217 \\
\hline With palm oil & 0.9972 & 1.127 & 1.330 \\
\hline With ash & 0.8677 & 0.8359 & 0.6906 \\
\hline Without additives & \multicolumn{3}{|}{} \\
\hline
\end{tabular}

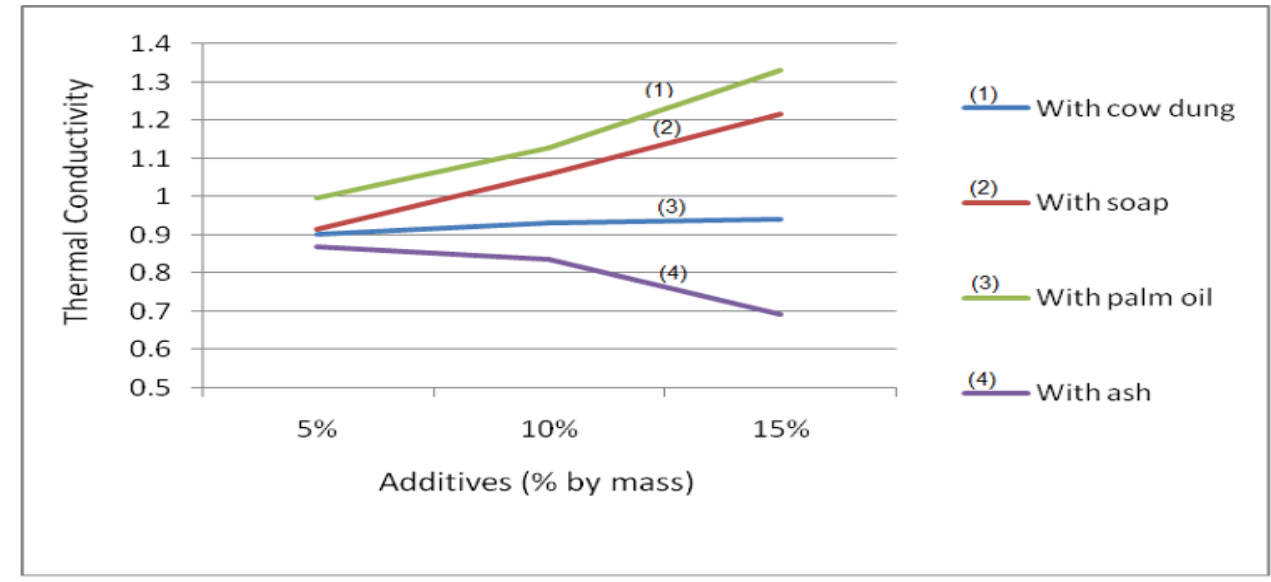

Figure (2): Thermal conductivity of the samples

This indicates that ash additives can be used to decrease the thermal conductivity of the mud. Decreasing the thermal conductivity of the mud is very important factor to increase its insulation capability and to achieving thermal comfort for its occupants. Insulation reduces unwanted heat loss or gain and can decrease the energy demands of heating and cooling systems.

In contrast with ash, the other additives increase the thermal conductivity of the mud. This might happen due to the reaction between the additives and the components of the mud, especially that mud differs from place to place. Thus needs more investigation to determine the main cause.

\section{CONCLUSION}

There are many examples across the world where the mud additives are effectively used. They can be used to improve the quality of the soil; e.g. dry strength, wet strength, water erosion, abrasion resistance, surface protection (table 2), etc. There are four sources of mud additives listed as follows; mineral, synthetic, vegetable and animal sources. Most of these additives are widely available, inexpensive or might be free.

Thermal conductivity in the mud brick is important for thermal insulation purposes. Heat will flow faster through materials that have higher conductivity. On the other hand, materials that have lower conductivity will be suitable to be used as a heat insulator. 
Four different additives (cow dung, soap, palm oil and ash) were examined to test their effect on the thermal conductivity of the mud bricks by using "Quick Thermal Conductivity Meter". The experiments indicated that the first three additives (cow dung, soap and palm oil) increased the thermal conductivity of the mud bricks, while the fourth additive (ash) decreased the mud's thermal conductivity.

Based on this, the ash can be mixed with mud to increase its insulation capability and to reduce unwanted heat loss or gain, which in turn will reduce the building's energy demands.

This experiment is worthily recommended to be repeated to cover many other additives which have been mentioned in this study. This will encourage and enhance the trend of building with mud bricks.

Finally, it is important to bear in mind that the quantity of additives varies from case to case based on the type of the additives and the soil conditions depending upon the properties required. The precise quantities of additives often need to be determined based on the observation and experiment, and by trial and error for each particular situation.

Table (2): Mud additives

\begin{tabular}{|c|c|c|c|c|c|c|c|c|}
\hline & & 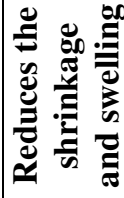 & 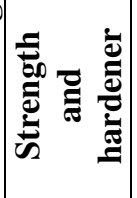 & 离 & 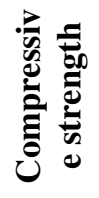 & 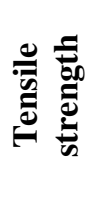 & 氧 & 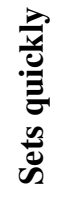 \\
\hline \multirow{3}{*}{ 宽 } & Sand & $\checkmark$ & & & $\checkmark$ & & & \\
\hline & Pozzolana & & $\checkmark$ & & $\checkmark$ & & $\checkmark$ & \\
\hline & Ashes & $\checkmark$ & $\checkmark$ & & & & & \\
\hline \multirow{7}{*}{ 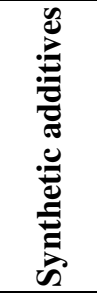 } & Portland cement & $\checkmark$ & $\checkmark$ & $\checkmark$ & $\checkmark$ & & $\checkmark$ & $\checkmark$ \\
\hline & Hydraulic lime & & $\checkmark$ & & & & & \\
\hline & Hydrated lime & & $\checkmark$ & & & & & \\
\hline & Gypsum & & & & $\checkmark$ & & & $\checkmark$ \\
\hline & Magnesium oxide & & & & $\checkmark$ & & & \\
\hline & Soap & & & $\checkmark$ & & & & \\
\hline & Bitumen & & & $\checkmark$ & & & & \\
\hline \multirow{7}{*}{ 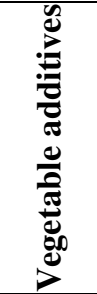 } & Fibers & & $\checkmark$ & & & $\checkmark$ & & \\
\hline & Vegetable Oils and Fats & & & $\checkmark$ & & & & \\
\hline & Tannins & & & $\checkmark$ & & & & \\
\hline & Gum Arabic & & & & $\checkmark$ & & & \\
\hline & Palmo copal & & & $\checkmark$ & & & & \\
\hline & Sap and latexes & & $\checkmark$ & & $\checkmark$ & & & \\
\hline & Molasses & & $\checkmark$ & & & & & \\
\hline \multirow{7}{*}{ 㞼 } & Fibers & & & & & $\checkmark$ & & \\
\hline & Blood & & $\checkmark$ & $\checkmark$ & & & & \\
\hline & Casein & $\checkmark$ & & & & & & \\
\hline & Animal glues & & $\checkmark$ & $\checkmark$ & $\checkmark$ & & & \\
\hline & Oils and fats & & & $\checkmark$ & & & & \\
\hline & Urine & $\checkmark$ & & & & & $\checkmark$ & \\
\hline & Excrements & $\checkmark$ & $\checkmark$ & & & & & \\
\hline
\end{tabular}




\section{REFERENCES}

1. Abdu, M. A., "Developing A Modern Technique for Clayey Construction", Conference on: Technology \& Sustainability in the Built Environment, College of Arch. \& Planning, King Saud University, Riyadh, (2010).

2. Agrawal , A., Konno, K., "Latex: A Model for Understanding Mechanisms, Ecology, and Evolution of Plant Defense Against Herbivory", Annual Review of Ecology, Evolution, and Systematics Vol. 40: 311-331 (2009).

3. AHMADI, S., Adobe conservation: Evaluation of silicone and acrylic consolidants, master thesis, Queen's University Kingston, Ontario, Canada, (2008).

4. Al-Jadeed, Mansour Abdul Aziz, "Mud Architecture in Arab \& Western Countries", Journal of Al-Madinah Al-Munawwarah Research \& Studies Center, Vol. 8, No. 2, pp 105-138. (2004)

5. Berhane, Z., "the Traditional use of Millet ("teff”) Stalk as Reinforcement for Clayey Building Materials", Vegetable Plants and their fibers as Building materials, Proceeding of the second International RILEM Symposium, P. C-37 (1990).

6. Browne, G., "Stabilized Interlocking Rammed Earth Block: Alternatives to cement Stabilization", Southampton Solent University, Proceedings of the 11th International Conference on Non-conventional Materials and Technologies (NOCMAT 2009), Bath, UK (2009).

7. Cornelis Klein, C., Hurlbut, Jr., " Manual of Mineralogy", John Wiley, 20th ed., pp. 352-353 (1985).

8. Fajobi, A.B. and O.O. Ogunbanjo, 1994. Effect of moisture content and wood ash on the strength of adobe bricks. B.Sc. Thesis. Obafemi Awolowo University, Ile-Ife (unpublished).

9. Fatih, T., Umit, A., "Utilization of Fly Ash in Manufaturing of Building Bricks", 2001 International Ash Utilization Symposium, Center for Applied Energy Research, University of Kentucky, paper \# 13.

10. Jurina , L., Righetti , M., "Traditional Buildings in Peru”. Earthquake-Safe: Lesson to be Learned from traditional construction, International Conference on the Seismic Performance of Traditional Buildings, Istanbul, Turkey, Nov.16-18, (2000).

11. Norton, J., "Building with Earth, a handbook." John Norton, IT Publications, Michael Watson, (2004).

12. Okunade, E.A., The effect of wood ash and sawdust admixtures on the engineering properties of a burnt laterite-clay brick. J. Applied Sci., 8: 10421048 (2008).

13. Practical Action, The Schumacher Centre for Technology \& Development Bourton-on-Dunsmore, Rugby, CV23 9Z, United Kingdom

14. Schicker, A., Gier, S., "OPTIMIZING THE MECHANICAL STRENGTH OF ADOBE BRICKS", Clays and Clay Minerals, The Clay Minerals Society, Volume 57, Number 4, pp. 494-501 (2009).

15. sustainability Institute: REPORT ON unfired (adobe) clay brick building system (2005). 
16. Torraca, G., "Porous Building Materials", Materials Science for Architectural Conservation, 3rd ed. Rome, Italy, (1988).

17. Watson, M., "Building with Earth, a handbook." John Norton, IT Publications, (1986).

18. http://buildearth.org/?p=241

19. http://en.wikipedia.org/wiki/Pozzolana

20. http://practicalaction.org/practicalanswers/product_info.php?products_id=204

21. http://www.britannica.com/EBchecked/topic/473488/pozzolana

22. http://www.epa.gov/heatisland/

23. http://www.fastonline.org/CD3WD_40/CD3WD/CONSTRUC/G48STE/EN/B1 549_6.HTM

24. http://www.greenspec.co.uk/html/materials/limemortar.html

25. http://www.undeerc.org/carrc/html/whatiscoalash.html

26. http://www.yourhome.gov.au/technical/fs56.html

27. http://practicalaction.org/practicalanswers/product_info.php?

28. http://www.nzdl.org /gsdlmod?

29. http://www.thefreedictionary.com/Sand

\section{المواد المحسنة لطوب الطيني وانعكاس ذلك على توصيله الحراري د. اء محمد بن علي باحبيل}

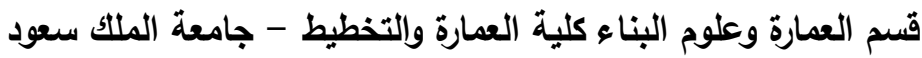

تعتبر مادة الطين من أققام مواد البناء استخداماً في تثييد المباني وذللك لكثرة توفرها وانخفاض تكلفتها اقتصادياً.

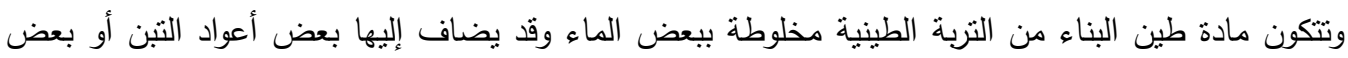

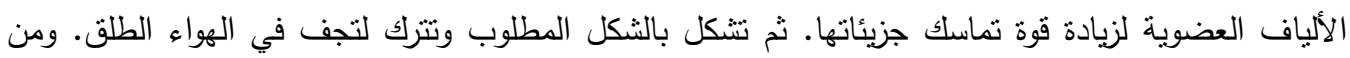

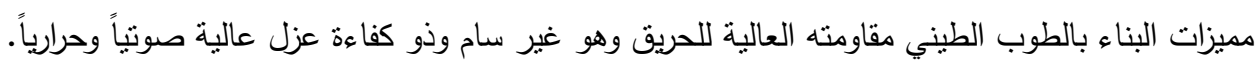
ومن الناحية الإنثائية؛ تعتبر الحوائط المبنية من الطوب الطيني حوائط حاملة مما تمكن من بناء مباني متعددة

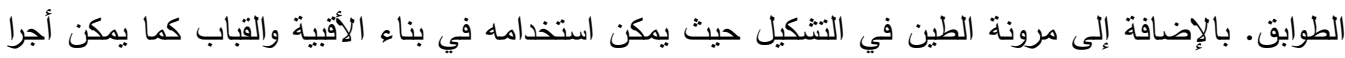

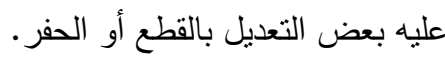

ومن ناحية أخرى يشوب البناء بالطين بعض الجوانب السلبية تتمثل في انخفاض تحمله نسبياً لقوة الضغط ، وانخفاض قوة الثد لدية، وانخفاض مقاومته للخشش وكذلك انخفاض مقاومته للماء. وللتخلب على هذه العيوب، يقوم البنائين بإضافة بعض المواد إليه لتحسين نوعيته وزيادة قدرته ورفع كفاءته. وتتعرض هذه الورقة إلى إلقاء الضوء على المواد المحسنة للطين والمستخدمة في مناطق مختلفة من العالم وعرض مزايا وعيوب كل مادة على حده والتي شملت المعادن والمواد الصناعية والمواد النباتية والحيوانية. كما تتضمن هذه الدراسة تجربة معملية تم من خلالها دارسة انز التوصيل الحراري للطوب الطيني بعد خلطه ببعض هذه المواد، بحيث نم اختيار مادة من كل صنف وهي: رماد و زيت نباتي وصابون ومخلفات الأبقار ، ثم تقبيم كفاءة كل مادة ومدى مساهمتها في رفع التوصيل الحراري للطوب. 